\title{
KONSELING KRISIS: SEBUAH PENDEKATAN DALAM MEREDUKSI MASALAH TRAUMATIK PADA ANAK DAN REMAJA
}

\author{
Sestuningsih Margi Rahayu \\ Program Studi Bimbingan dan Konseling, FKIP, Universitas Mulawarman \\ E-mail: rahayusestuningsih@gmail.com
}

\begin{abstract}
Abstrak
Masalah kekerasan seksual, bullying dan perceraian dalam beberapa tahun terakhir mengalami peningkatan yang signifikan sehingga meninggalkan dampak traumatik yang sangat dalam kepada anak dan remaja. Traumatik yang ditimbulkan akan berdampak kepada aktivitas-aktivitas perilaku yang muncul seperti depresi, penyangkalan, malu, ketakutan, kesedihan, membolos, mimpi buruk, berbohong, dan psikosomatis. Oleh sebab itu dampak dari masalah yang dihadapi oleh anak dan remaja harus segera diatasi dengan intervensi yang tepat. Konseling krisis untuk mereduksi traumatik pada anak dan remaja meliputi konsep konseling krisis, tujuan dan fokus konseling krisis, teknik konseling krisis serta peran konselor dalam konseling krisis dan implementasi konseling krisis dalam mereduksi traumatik pada anak dan remaja.
\end{abstract}

Kata Kunci: konseling krisis, reduksi, traumatik.

\section{Abstract}

The problem of sexual violence, bullying and divorce in recent years has increased significantly, leaving a very deep impact traumatic to children and adolescents. Traumatic generated will affect the activities of emergent behavior such as depression, denial, shame, fear, sadness, ditching, nightmares, lying, and psychosomatic. Therefore, the impact of the problems faced by children and adolescents must be addressed with appropriate intervention. Crisis counseling to reduce traumatic in children and adolescents include crisis counseling concepts, goals and focus on crisis counseling, crisis counseling techniques and the role of counselor in crisis counseling and implementation of crisis counseling in reducing traumatic in children and adolescents.

Keywords: crisis counseling, reduction, traumatic

\section{PENDAHULUAN}

Masalah kekerasan seksual, bullying dan perceraian dalam beberapa tahun terakhir mengalami peningkatan yang signifikan dan memberikan dampak traumatik yang sangat dalam bagi anak dan remaja yang mengalami hal tersebut. Berdasarkan data Komisi Perlindungan Anak Indonesia (KPAl) pada tahun 2016 merilis bahwa Indonesia pada saat ini mengalami kondisi lampu merah kejahatan seksual pada anak maupun remaja dan meningkat $100 \%$ dari tahun sebelumnya (kpai.go.id, 28 juli 2016). Data UNICEF menunjukkan satu dari 10 anak perempuan di dunia menjadi korban kejahatan seksual (liputan6.com, 28 juli 2016). Kejahatan seksual tidak hanya menimpa anak perempuan saja tetapi dialami juga oleh anak laki-laki seperti kasus sodomi.

Kasus lain yang banyak dialami anak dan remaja adalah kasus bullying. Data dari Komisi Perlindungan Anak Indonesia (KPAI) menunjukkan bahwa terdapat peningkatan yang signifikan kasus perilaku kekerasan (bullying) dari 67 kasus pada tahun 2014 menjadi 79 kasus pada 2015 (Republika.co.id, 30 Desember 2015). Berdasarkan survei oleh Plan Indonesia dan SEJIWA pada 1500 pelajar SMP dan SMA di 3 kota besar yaitu Jakarta, Yogyakarta, dan Surabaya pada tahun 2008 terdapat $67 \%$ pelajar SMP dan SMA menyatakan tindak bullying pernah terjadi di sekolah mereka. Pelakunya adalah teman, kakak kelas, adik kelas, guru, kepala sekolah, dan preman yang berada di sekitar sekolah (Kompas.com, 27 November 2008). Pada tahun 2005 seorang siswi SMP melakukan bunuh diri, akibat tidak tahan dengan ledekan dari teman-temannya yang mengatai ia sebagai anak tukang bubur (liputan6.com, 07 Oktober 2008).

Kasus lain yang berdampak traumatik pada anak dan remaja adalah kasus perceraian. Tingkat perceraian di Indonesia saat ini sangat tinggi sekali sehingga banyak mempengaruhi dan meninggalkan dampak traumatik kepada anak dan remaja. Berdasarkan data dari BKKBN tahun 2013 tingkat perceraian di Indonesia sudah menempati urutan tertinggi se-Asia Pasifik dan tahuntahun berikutnya terus mengalami peningkatan. Berdasarkan data yang dirilis oleh Kementerian Agama Republik Indonesia tahun 2014, diketahui bahwa terdapat hampir rata-rata 959 kasus perceraian per hari atau 40 perceraian setiap jamnya (Republika.co.id, 10 April 2016). Hal ini menunjukkan bahwa perceraian merupakan salah satu kasus yang sangat tinggi intensitasnya. 
Perceraian yang begitu tinggi akan mempengaruhi penderitaan kepada anak dan remaja. Penderitaan yang ditimbulkan akan mengakibatkan kecemasan, kesakitan, depresi dan trauma yang berkepanjangan. Menurut Yusuf (2005) dampak yang ditimbulkan dari sebuah perceraian merupakan masalah yang serius sehingga perlu mendapatkan perhatian lebih dari berbagai pihak. Sedangkan menurut Fadila (2013) dampak buruk dari perceraian bagi anak dan remaja adalah kecenderungan meminum alkohol, menggunakan obat-obatan terlarang bahkan ingin bunuh diri.

Kasus-kasus yang terjadi tentu sangat besar sekali pengaruhnya bagi anak dan remaja sehingga meninggalkan dampak traumatik yang begitu mendalam seperti depresi, penyangkalan, malu, ketakutan, kesedihan, membolos, mimpi buruk, berbohong, dan psikosomatis dan sebagainya. Oleh sebab itu diperlukan intervensi yang tepat salah satunya melalui konseling krisis. Konseling krisis digunakan sebagai salah satu intervensi dalam proses penyembuhan. Konseling krisis memiliki keunikan dan kontribusi antara lain: pendekatan ini memberikan keuntungan karena singkat dan langsung, pendekatan ini menggunakan tujuan dan maksud yang sederhana karena sifat yang tiba-tiba dan/atau traumatis, pendekatan ini berlangsung pada intensitas yang lebih besar daripada bentuk konseling biasa, sifatnya lebih transisional.

\section{PEMBAHASAN}

\section{Pengertian Trauma}

Trauma menurut Chaplin (2001) adalah suatu luka baik yang bersifat fisik, jasmani maupun psikis. Trauma dapat menimbulkan gangguan kecemasan. Menurut Strauser, dkk (2006) Trauma merupakan peristiwaperistiwa yang melibatkan individu yang di tunjukkan dengan suatu insiden yang memungkinkan ia terluka atau mati sehingga muncul perasaan diteror dan putus asa. Sedangkan menurut Golemen (2001) bahwa penderita trauma mengalami perubahan sirkuit limbik yang berpusat pada amigdala. Sehingga trauma adalah peristiwa yang melibatkan individu mengakibatkan suatu insiden yang dapat mempengaruhi fisik, jasmani maupun psikis.

\section{Gejala Trauma}

Menurut Corrigen, Selassie, Orman (2010) menjelaskan ada tiga macam gejala utama trauma yaitu: re-experiencing atau mengingat kembali. Korban trauma umumnya terus mengalami atau menghidupkan kembali trauma mereka dalam bentuk yaitu memiliki kenangan buruk seperti gambar, persepsi, maupun pemikiran yang berkaitan dengan trauma, mengalami mimpi buruk tentang suatu kejadian, merasa bahwa kejadian tersebut akan terulang kembali, gejala fisik seperti berkeringat, detak jantung lebih cepat, susah bernafas ketika teringat pada kejadian traumatik.

Arousal atau rasa takut dan cemas berlebihan seperti susah tidur, cepat marah, mudah kaget atau ketakutan jika ada sesuatu atau seseorang yang datang tanpa kita sadari, sulit berkonsentrasi, merasa gelisah dan terus mencari adanya bahaya, panik. Avoidance atau menghindar seperti menghindari pikiran, perasaan maupun pembicaraan yang mengingatkan trauma, menghindari tempat, aktifitas ataupun orang yang mengingatkan trauma, kehilangan minat atau tidak berpartisipasi dalam kegiatan yang disukai, merasa putus hubungan dengan orang lain, merasa seolah-olah masa depannya pendek atau tidak punya harapan.

\section{Konsep Dasar Konseling Krisis}

Konseling krisis adalah penggunaan beragam pendekatan langsung dan berorientasi pada tindakan untuk membantu individu menemukan sumber daya di dalam dirinya atau menghadapi krisis secara eksternal. Dalam semua bentuk konseling krisis pelayanan cepat dan efisien diberikan dalam cara khusus (Gladding, 2012). Menurut James (dalam Gladding, 2012) krisis adalah persepsi atau pengalaman akan sesuatu peristiwa atau situasi sebagai kesulitan yang tidak dapat ditorerir yang melebihi sumber daya dan kemampuan seseorang untuk mengatasinya saat itu.

\section{Sudut Pandang Tentang Sifat Manusia}

Kehilangan adalah bagian kehidupan yang tidak dapat dielakkan. Baik melalui perkembangan maupun situasi, manusia sehat tumbuh dan melanjutkan kehidupannya, meningggalkan sesuatu di belakang baik secara sengaja, tidak sengaja atau karena bertumbuh. Manusia dapat mengalami berbagai macam krisis, empat tipe yang paling umum adalah perkembangan yaitu terjadi secara normal di dalam pertumbuhan dan perkembangan manusia pada situasi yang dianggap normal (misalnya kelahiran seorang anak, pensiun), situasional yaitu terjadinya peristiwa yang tidak bisa dan tidak umum, yang tidak dapat diprediksi tau dikendalikan (misalnya kecelakaan, lalu lintas, penculikan dan kehilangan pekerjaan), eksistensial yaitu melibatkan konflik dan ansietas yang menyertai persoalan penting manusia seperti tujuan, tanggung jawab, kemandirian, kebebasan dan komitmen, (contohnya seseorang yang menyadari pada usia 50 tahun bahwa dia telah menyia-nyiakan kehidupannya dan tidak dapat kembali ke masa lalu), ekosistemik yaitu di mana bencana yang disebabkan oleh alam ataupun manusia secara tiba - tiba mengenai diri seseorang ataupun sekelompok orang yang menemukan diri, bukan melalui kesalahan atau tindakannnya, 
dibanjiri akibat suatu kejadian yang dapat memberi pengaruh buruk pada hampir semua makhluk dalam lingkungan tempat dia hidup (misalnya topan, tsunami, aksi terorisme) ( Gladding, 2012).

\section{Tujuan dan Fokus Konseling Krisis}

Tujuan dari konseling krisis adalah berkisar pada memberikan bantuan segera dan dalam berbagai bentuk kepada orang yang membutuhkan misalnya psikologis, keuangan dan hukum. "Apa yang terjadi selama krisis menentukan apakah krisis akan menjadi wadah penyakit yang akan berubah menjadi kondisi yang kronis dan bersifat jangka panjang atau tidak. Pada awalnya konselor menggunakan teori dasar krisis untuk membantu "orang dalam krisis mengenali dan membetulkan penyimpangan afektif, tingkah laku, kognitif yang temporer yang disebabkan peristiwa traumatis (Gladding, 2012).

Pelayanan ini berbeda dengan konseling singkat, yang mencoba membantu orang menemukan penyembuhan atas masalah yang sedang terjadi. Penyesuaian jangka panjang dan kesehatan membutuhkan tindak lanjut cukup banyak dari pihak konselor krisis atau ahli spesialis lainnya.

\section{Teknik Konseling Krisis}

Teknik yang digunakan dalam konseling krisis sangat beragam sesuai tipe krisis dan akibat yang ditimbulkannya. Menurut James (dalam Gladding, 2012) apa yang dilakukan seorang pekerja krisis dan kapan dia melakukannya tergantung pada hasil penilaian terhadap pengalaman krisis seseorang yang dilakukan secara kontinu dan dan mengalir. Setelah penilaian ada tiga aktivitas mendengarkan yang esensial yang harus diterapkan antara lain mendefinisikan masalah yaitu mengeksplorasi dan mendefinisikan masalah dari sudut pandang klien, menggunakan teknik mendengarkan dengan aktif, termasuk pertanyaan terbuka, memperhatikan pesan-pesan yang disampaikan klien secara verbal maupun nonverbal, memastikan keselamatan klien yaitu menilai tingkat bahaya, kritis, imobilitas, atau keseriusan ancaman terhadap keselamatan fisik, dan psikologis klien dan jika perlu memastikan bahwa klien menyadari alternatif lain selain tindakan impulsif yang dapat menghancurkan diri sendiri, menyediakan dukungan yaitu berkomunikasi dengan klien bahwa pekerja krisis adalah sosok pendukung yang tepat peragakan kepada klien (dengan kata-kata, suara dan bahasa tubuh) keterlibatan personal yang penuh kasih sayang, positif, non-posesif, tidak menghakimi dan menerima.

Setelah dan kadang-kadang selama, pertengahan mendengarkan tersebut di gunakan strategi bertindak yang melibatkan antara lain memeriksa alternatif lain yaitu membantu klien dalam mengeksplorasi pilihanpilihan yang dia punyai saat ini, memfasilitasi pencarian dukungan situasional yang mendesak, mekanisme bertahan dan pikiran yang positif, membuat rencana yaitu membantu klien dalam mengembangkan rencana jangka pendek yang realistis yang mengidentifikasi sumber daya tambahan dan menyediakan mekanisme bertahan. Langkah tindakan yang dapat dimiliki dan dipahami oleh klien, mendapatkan komitmen yaitu membantu klien berkomitmen terhadap dirinya sendiri untuk menentukan tindakan yang positif yang dapat dimiliki dan dicapai atau diterima oleh klien secara realistis.

\section{Peranan Konselor}

Konselor yang bekerja pada kondisi krisis harus merupakan individu yang matang kepribadiannya serta mempunyai banyak pengalaman kehidupan yang telah dia hadapi dengan sukses. Konselor harus mempunyai keahlian dasar untuk memberi bantuan, berenergi tinggi, mempunyai refleks mental yang cepat, tetapi juga seimbang, kalem, kreatif, dan fleksibel dalam menghadapi situasi sulit. Konselr sering kali terarah dan aktif dalam situasi krisis. Perannya cukup berbeda dari konseling biasa.

\section{Kekuatan dan Kontribusi Konseling Krisis}

Sebagai sebuah spesialitas, konseling krisis mempunyai keunikan dan kontribusi pada profesi konseling sebagai berikut yaitu pendekatan ini memberikan keuntungan karena singkat dan langsung, pendekatan ini menggunakan tujuan dan maksud yang sederhana karena sifat krisis yang tiba-tiba dan/atau traumatis, pendekatan ini bergantung pada intensitas yang lebih besar dari pada bentuk konseling biasa, pendekatan ini sifatnya lebih transisional. Keterbatasan konseling krisis yaitu pendekatan ini berhadapan dengan situasi yang harus ditangani dengan cepat, pendekatan ini tidak memberi resolusi sedalam seperti yang dilakukan pendekatan konseling lain, pendekatan ini lebih terbatas waktu dan berorientasi pada trauma dibanding kebanyakan bentuk intervensi terapi lainnya.

\section{Implementasi Konseling Krisis untuk Mereduksi Masalah Traumatik Pada Anak dan Remaja}

Kekerasan seksual, bullying dan perceraian merupakan hal yang sangat merugikan dan menakutkan bagi anak dan remaja. Hal tersebut harus dicegah dan tidak boleh terjadi kepada anak dan remaja karena memiliki dampak yang spesifik terhadap perkembangan anak dan remaja. Berbagai dampak atas kekerasan seksual, bullying dan perceraian mengakibatkan traumatik yang sangat mendalam kepada anak dan 
remaja. Perilaku-perilaku yang dimunculkan oleh anak dan remaja seperti frustasi, kurang berprestasi, murung, merasa bersalah, kurang percaya diri hingga hilang jati diri. Dampak ini perlu di selesaikan dengan cepat dan singkat.

Konseling krisis sebagai sebuah pendekatan yang arahnya kepada intervensi pada hal-hal yang sifatnya traumatik akan membantu dalam proses penyembuhan. Hal ini berdasarkan tujuan dari konseling krisis yaitu memberi bantuan segera dan dalam berbagai bentuk kepada orang yang membutuhkan (Gladding, 2012). Konseling krisis dapat berjalan efektif apabila konselor memiliki kepribadian yang matang, pengalaman dan keahlian dasar untuk memberi bantuan, benergi tinggi, mempunyai reflek mental yang cepat, seimbang, kalem, kreatif, fleksibel dalam menghadapi perilaku yang sulit. Contohnya kasus sebelum treatment dilakukan: klien mengalami depresi karena kedua orang tuanya bercerai, gejala yang muncul adalah kesedihan dan ketakutan, merasa putus asa dan tidak bahagia. Proses treatment dilakukan berdasarkan penilaian terhadap kasus yang dialami klien, konselor fokus terhadap traumatik yang dialami dan aktivitas-aktivitas perilaku yang muncul, setelah itu konselor melakukan eksplorasi dan mendefinisikan masalah klien dari sudut pandangnya, memberikan penguatan-penguatan agar klien tetap merasa dirinya didengarkan dan diterima, kemudian melakukan rencana yang realitis, dapat dipahami dan kemudian klien mampu melakukannya secara baik dan positif. Setelah itu dilakukan evaluasi terhadap komitmen keputusan yang telah dipilih oleh klien.

\section{PENUTUP}

\section{Simpulan}

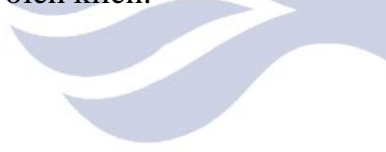

Dalam mereduksi traumatik akibat kekerasan seksual, bullying dan perceraian dan proses pengembangan kepribadian individu kearah yang postif dan lebih baik, konseling krisis dapat di gunakan sebagai intervensi. Pertimbangan konseling krisis sebagai intervensi yaitu pendekatan konseling krisis diberikan secara khusus, cepat, singkat, langsung, efisien dalam proses pelayanan, pendekatan menggunakan tujuan dan maksud sederhana karena sifat krisis yang tiba-tiba dan/atau traumatis, pendekatan ini tergantung pada intensitas yang lebih besar dari pada bentuk konseling biasa, konselor yang bekerja dalam konseling krisis memiliki kepribadian yang matang, memiliki pengalaman kehidupan, memiliki keahlian dasar untuk memberikan bantuan, berenergi tinggi, mempunyai refleks mental yang cepat, tetapi juga seimbang, kalem, kreatif, dan fleksibel dalam menghadapi situasi yang sulit.

\section{DAFTAR PUSTAKA}

BKKBN. go.id (diakses pada tanggal 10 April 2016).

Chaplin, J.P. 2001. Kamus Lengkap Psikologi. Jakarta: Grafindo.

Corrigen, J.W. Selassie, A.W. dan Orman, J.A. The Epidemiology Traumatic Brain Injury. Journal of Head Trauma Rehabilitation 25: 72-80.

Fadila, R. 2013. Dampak Buruk Perceraian Bagi Anak. (online)http://www.bisnis-iabar.com/index.php/berita/ ini-dampak-buruk-perceraian-bagi-anak. (Diakses 10 April 2016).

Gladding, S. 2012. Konseling Profesi yang Menyeluruh. Jakarta: Indeks.

Golemen, D. 2001. Emotional Intelegence: Kecerdasan Emosional, Mengapa EI Lebih Penting daripada IQ. Jakarta: Gramedia.

http://m.liputan6.com/global/read/2101694/unicef-1dari10-anak-perempuan-alami-pelecehan-seksual. (Diakses 28 Juli 2016).

http://m.liputan6.com/news/read/105426/gara-garasering-diejek-vivi-gantung-diri. (Diakses 07 Oktober 2008).

http://m.republika.co.id/berita/nasional/umum/30/12/30/o 067zt280-kpai-kasus-bullying-di-sekolah-meningkatselama-2015. (Diakses 30 Desember 2015).

http://m.republika.co.id/indeks/hottopic/perceraian (Diakses 10 April 2016).

http://tekno.kompas.com/read/2008/11/27/19465378/awa s.bullving.di-sekolah-sekolah.yogya. (Diakses 27 November 2008).

http://www.kpai.go.id/berita/kpai-pelecehan-seksualpada-anak-meningkat-100. (Diakses 28 Juli 2016).

Strauser, D. dkk. 2006. Trauma Symptoms.Relationship With Career Thoughts, Vocational Identity and Developmental Work Personality, 4 (54): 346-357.

Yusuf, S \& Nurihsan, J. 2005. Landasan Bimbingan dan Konseling. Bandung: Remaja Rosda Karya. 